\title{
A novel esterase gene cloned from a metagenomic library from neritic sediments of the South China Sea
}

\author{
Qing Peng ${ }^{1}$, Xue Zhang ${ }^{1}$, Meng Shang ${ }^{1}$, Xu Wang ${ }^{1}$, Guili Wang ${ }^{1}$, Bingxue Li ${ }^{1}$, Guohua Guan ${ }^{1}$, Ying Li ${ }^{1 *}$ and \\ Youshao Wang ${ }^{2}$
}

\begin{abstract}
Background: Marine microbes are a large and diverse group, which are exposed to a wide variety of pressure, temperature, salinity, nutrient availability and other environmental conditions. They provide a huge potential source of novel enzymes with unique properties that may be useful in industry and biotechnology. To explore the lipolytic genetic resources in the South China Sea, 23 sediment samples were collected in the depth $<100 \mathrm{~m}$ marine areas.

Results: A metagenomic library of South China Sea sediments assemblage in plasmid vector containing about 194 $\mathrm{Mb}$ of community DNA was prepared. Screening of a part of the unamplified library resulted in isolation of 15 unique lipolytic clones with the ability to hydrolyze tributyrin. A positive recombinant clone (pNLE1), containing a novel esterase (Est_p1), was successfully expressed in E. coli and purified. In a series of assays, Est_p1 displayed maximal activity at $\mathrm{pH} 8.57,40^{\circ} \mathrm{C}$, with $\rho$-Nitrophenyl butyrate $\left(\mathrm{C}_{4}\right)$ as substrate. Compared to other metagenomic esterases, Est_p1 played a notable role in specificity for substrate $C_{4}\left(K_{\text {cat }} / K_{\mathrm{m}}\right.$ value $\left.11,500 \mathrm{~S}^{-1} \mathrm{~m} \mathrm{M}^{-1}\right)$ and showed no inhibited by phenylmethylsulfonyl fluoride, suggested that the substrate binding pocket was suitable for substrate $\mathrm{C}_{4}$ and the serine active-site residue was buried at the bottom of substrate binding pocket which sheltered by a lid structure.
\end{abstract}

Conclusions: Esterase, which specificity towards short chain fatty acids, especially butanoic acid, is commercially available as potent flavoring tools. According the outstanding activity and specificity for substrate $C_{4}$, Est_p1 has potential application in flavor industries requiring hydrolysis of short chain esters.

Keywords: metagenomic library, functional screening, esterase, South China Sea

\section{Background}

Marine microbes are a large and diverse group, and are exposed to a wide variety of pressure, temperature, salinity, nutrient availability, and other environmental conditions [1-3]. They provide a huge potential source of novel enzymes with unique properties that may be useful in industry and biotechnology.

Lipolytic enzymes are ubiquitous in nature, and microbial lipolytic enzymes are commercially significant $[4,5]$. In a classification scheme based on substrate

\footnotetext{
* Correspondence: yingli528@vip.sina.com

'State Key Laboratories for Agro-biotechnology and College of Biological

Sciences, China Agricultural University, Beijing, 100193, P. R. China

Full list of author information is available at the end of the article
}

preference, lipolytic enzymes are divided into lipases (EC 3.1.1.3) that hydrolyze long-chain acylglycerols $\geq 10$ carbon chain), and esterases (EC 3.1.1.1) that hydrolyze short-chain acylglycerols $\leq 10$ carbon chain). Both groups of biocatalysts have characteristics making them useful in a wide variety of industrial, pharmaceutical, biochemical, and biotechnological applications; e.g., they have high chemo-, region- and stereo-selectivity, stability in organic solvents, usually do not require cofactors, and do not catalyze side reactions $[6,7]$.

Lipolytic enzymes are serine hydrolases that share structural and functional characteristics such as an $\alpha / \beta$ hydrolase fold. Their catalytic mechanism involves a catalytic triad, or cofactor-independent activity [6]. Based

\section{Biomed Central}


on comparisons of amino acid sequences and biological properties, prokaryote-derived lipolytic enzymes have been classified into eight families, termed true lipases (family I), the enzymes display a Gly-Asp-Ser-(Leu) [GDS(L)] motif containing the active-site Ser (GDSL, family II), family III, hormone-sensitive lipases (HSL, family IV), and families V VIII [4].

A culture-independent approach, termed "metagenomics" $[8,9]$, allows screening for novel lipolytic enzymes, with industrial potential, from diverse environments [10]. For example, genes encoding lipolytic enzymes have been isolated from metagenomic libraries constructed from environmental samples including forest soils [11,12]; pond, lake, and river water [13-15] and hot spring and marine sediments $[16,17]$. With only a few exceptions, characteristics of the novel enzymes found so far are not very appropriate for industrial applications. Thus, further metagenomics-based search for novel lipolytic enzymes from different sources, and with greater industrial applicability, is an important task.

The offshore marine environment of the northern South China Sea, near the southern China continental shelf and Hainan Island (Additional file 1, Table S1), contains nutrient-rich waters with concentrations of organic compounds and diversity of marine microbes greater than those of most other regions of the open ocean. We collected sediment samples from this area, and performed functional screening for novel lipolytic enzymes using a metagenomic library.

\section{Results and discussion}

\section{High efficient screening for lipolytic enzymes}

Marine sediment samples from the South China Sea were collected from 23 sampling sites, depth $<100$ m (Additional file 1, Table S1). A metagenomic library was constructed using $\sim 2.1 \mu \mathrm{g}$ of sediment DNA, and contained $\sim 118,000>$ 90\%) recombinant colonies. Using 1217 recombinant plasmids, the library DNA insert size was estimated as $1.0 \sim 8.5$ $\mathrm{kb}$. The metagenomic library represented $\sim 194 \mathrm{Mb}$ of microbial community DNA of the marine sediment. A portion of the unamplified library $(\sim 60,000$ colonies $)$ was screened from screening plates. After $72 \mathrm{hr}$ incubation at $37^{\circ} \mathrm{C}, 15$ colonies were selected on the basis of stable hydrolysis zone and the lipolytic-positive plasmids were sequenced (Additional file 1, Table S2). The putative esterases, $\beta$-lactamases, phospholipases and patatin-like esterase were isolated from 49 identified genes.

It looks that pUC18 was useful vector for constructing small-insert metagenomic libraries, because of its high cloning and throughput screening efficiencies toward small-size target genes [18]. The pUC shotgun metagenomic library displayed the ability to rapidly assess large numbers of clones, avoiding the need for another subcloning library to obtain functional target genes.

\section{A novel lipolytic enzyme Est_p1}

One clone showed strong lipolytic activity, and was designated as pNLE1 (EU628679). pNLE1 had an insert of $3650 \mathrm{bp}$, with $53.76 \% \mathrm{G}+\mathrm{C}$ content and four ORFs. Based on complete domain of $\alpha / \beta$ hydrolase fold-1 (PF00561) related to esterase/lipase superfamily, the ORF that encoded a 296 amino acids protein was identified as a putative lipase/esterase gene (designated as est_p1).

This encoded protein showed $81 \%$ amino acids identity with a lipolytic enzyme (ACF67850) from uncultured bacteria [19]. Most of the other close matches also came from uncultured bacteria of environmental samples obtained from deep-sea sediment in the South China Sea [19], or from soil of the Gwangneung forest in Korea [20]. None of these lipolytic enzymes were previously characterized. The closest match, aside from environmental samples, was an $\alpha / \beta$ hydrolase fold protein (YP_001310323) from Clostridium beijerinckii NCIMB 8052, also unpublished, showing 53\% amino acids identity.

A putative ribosome binding site (RBS), GAGG, was detected upstream of the start codon at -12 to -9 region [21]. A strong promoter signal was found in the 28722827 bp range of pNLE1, located at the up-stream sequences of nle1_3, which might share the same promoter with Est_p1. SignalP3.0 analysis indicated that neither the cleavage site nor the N-terminal signal peptide was present in the whole gene [22], suggesting that Est_p1 may be expressed as a full-length protein, without requirement of flanking sequences or genes [23].

\section{Phylogenetic relationships of Est_p1}

Multiple sequence alignment of Est_p1 and lipolytic proteins revealed the typical catalytic triad of active site serine $\left(\mathrm{S}^{118}\right)$ motif $\mathrm{G}-\mathrm{x}-\mathrm{S}-\mathrm{x}-\mathrm{G}$, conserved aspartic acid $\left(\mathrm{D}^{244}\right)$, and histidine $\left(\mathrm{H}^{272}\right)$ residue motif in the encoded protein. Bacterial lipolytic enzymes have been classified into distinct families on the basis of their amino acid sequences and biochemical properties [4]. In order to classify Est_p1, a phylogenetic tree was constructed using many lipolytic enzymes [24] representing eight different families. The results suggest that Est_p1 belongs to family V (Figure 1). Multiple sequence alignment of Est_p1 and family V members, including enzymes from cold-adapted organisms (Moraxella sp., Psychrobacter immobilis, 24-31\% identity) [25,26], mesophilic bacteria (Haemophilus influenza, Brevibacterium linens, 23-24\% identity) [27], methylesterase-producing bacteria (Streptomyces purpurascens, 33\% identity) [28], solvent-producing bacteria (Clostridium beijerinckii, 53\% identity) [29] and other uncultured bacteria ( $81 \%$ sequence identity) [19] showed relationship mainly to four subfamilies of family $\mathrm{V}$. The alignment results showed three typical 


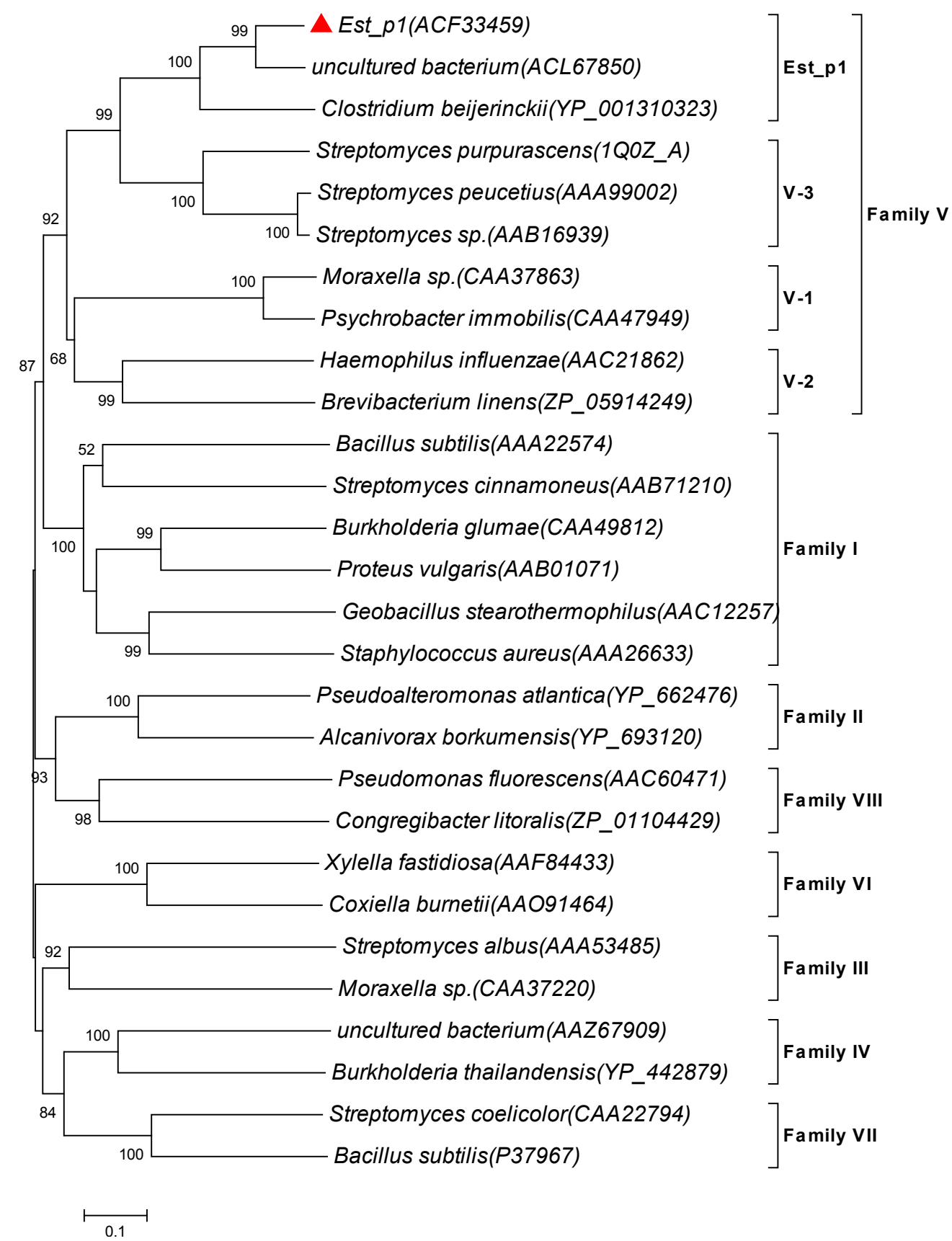

Figure 1 Unrooted neighbor-joining phylogenetic tree of Est_p1 (red triangle) and relatives, based on conserved sequence motifs of bacterial lipolytic enzymes. Amino acid sequences of other lipolytic enzymes were obtained from published data. Sequence alignment was performed using ClustalW version 2.0, and the tree was created by MEGA version 4.0. Scale bar at bottom indicates number of amino acid substitutions per site.

conserved motifs in Est_p1 and its subfamily. Of these, the $\eta 1$ helix motif (Q-L-x-x-W, amino acid 33-37) and 36-7 stand motif (amino acid 67-89) may construct a characteristic cap structure in the subfamily (Figure 2). Members of the Est_p1 subfamily, which come from organic degradation organisms as above, are more likely to be related to each other than to other members of family $\mathrm{V}$, and also show a functional relationship, i.e., they specifically hydrolyze short-chain acylglycerols. Taken together, these findings indicate that Est_p1 is a new member of family $\mathrm{V}$, belonging to a relatively independent subfamily. 


$\begin{array}{ll} & \text { Est_p1 } \\ 1 \text { Est_p1 } \\ \text { ACL67850 } \\ \text { YP } 001310323 \\ 2 \text { 100Z A } \\ \text { AAA99002 } \\ \text { AAB16939 } \\ 3 \text { AAC21862 } \\ \text { AP } 05914249 \\ 4 \text { CAA } 37863 \\ \text { CAA47949 }\end{array}$

Est_p1 ACL 67850 YP 001310323

2 1Q0 Z_A

AAA9 9002

AAB16939

3 AAC2 1862

4 CAA 37863

CAA47949

Est_p1
1 Est_p1
ACL67850
YP_001310323
2 1Q0Z_A
AAA99002
AAB16939
3 AAC21 1862
ZP_05914249
4 CAA 37863
CAA47949

1 Est_p1

\section{$\stackrel{\beta 1}{\rightarrow} \underset{T T}{\longrightarrow} \stackrel{\beta 3}{\longrightarrow} \mathrm{TT} \quad$ -}

AN I IANGI A I TNANGIQ IEYDTFGKSGEPA. AR INANGI|Q|I QYEIFGEKTNPT. R IVPSGDVELWSDDFGDPADPA. RMITNDEVTTLWSEGLGDPADAP. PTRMITKDEVTTISSEIGDPADAP. .KSLLNYQFHQVKQTINTPV MLLKRLGLAALFSLSMVGCTTAPNTLAVNTTQKITQYERSKSDLEVKSLTLASGDKMVYAENDNVTGEP. MLLKRLCFAALFSLSMVGCTNAPNALAVNTTOKIIQYERNKSDLEIKSLTLASGDKMVYAENGNVAGEP.

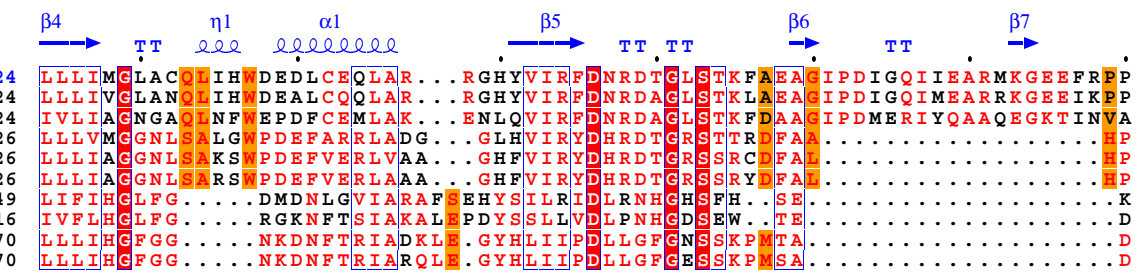

$\alpha 2$ -... $\frac{\beta 8}{10}$ eeceeeeles $\eta_{2}$ $\beta 9$

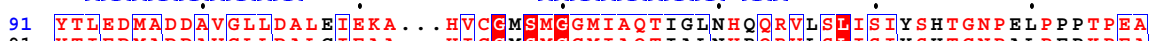

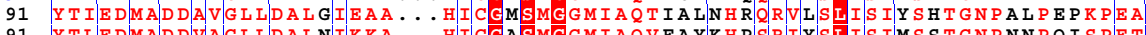

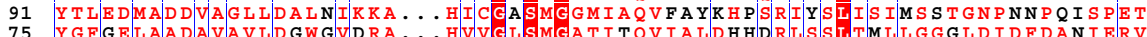

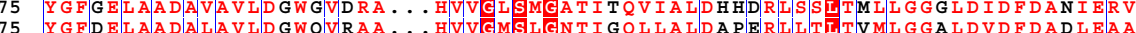

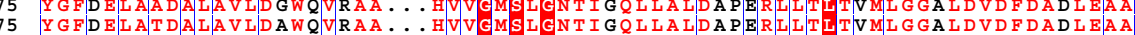

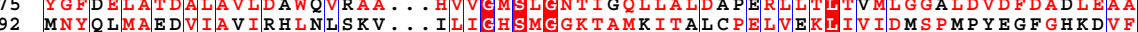

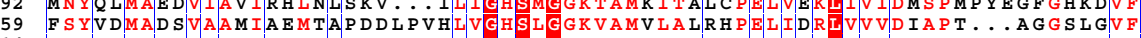

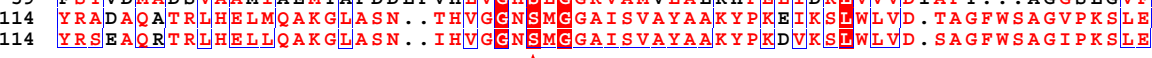

$\alpha 4$ $\alpha 5$

Est_p1

1 Est 1 ACL 67850

2 YP 0013103

AAA9 9002

AAB16939

3 AAC2 1862

ZP 05914249

4 CAA3 37863
CAA4 7949

elecelelececes

elecelecele

$\begin{array}{ll}158 & \\ 158 & \text { L } \\ 158 & \text { L } \\ 142 & \text { M } \\ 142 & \text { L } \\ 142 & \text { L } \\ 159 & N \\ 126 & \text { E } \\ 181 & \text { GA } \\ 181 & \end{array}$

E $\dot{\mathrm{Y}} \mathrm{I} \mathrm{V}$ T.

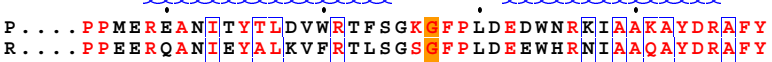

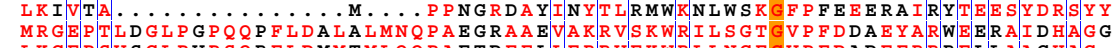

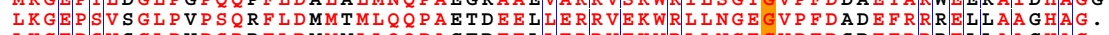

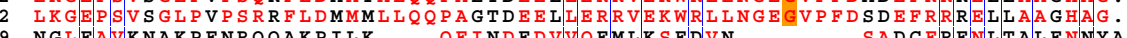

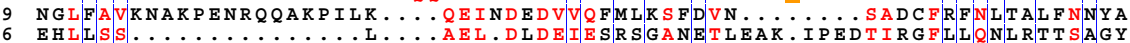

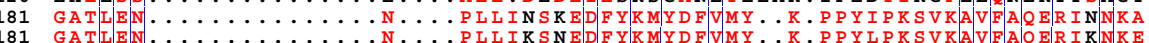

Est_p1

1 Est_p1

ACL 67850

YP 001310323

$2100 \mathrm{Z}$ A

AAA9 9002
AAB16939

3 AAC21862

3 AAC21862

ZP 05914249

CAA37863

$\eta 3$

T T.

$\eta 3$

$\eta 4$

$\alpha 6$ 209 PËG . . VARQMAAVLT QKNRKFELGSVTMP 209 PEG... VARQMAAVLTQKNRKFE LGSVTMP

209 PQG...AAVRQNAALVANGDRRQHILSIITV

212
211 TLA . E EPYAHYSLTLPPPSRAAELREVTVE

211 TFD..EPIVHHMIPQPPVSRGAEILARITT

175 AWQPNLTLLHESLPTIGDFPDMGEASFDG

229 L...DTKILEQIVTDNVEERAKIIIAKY Y IP

\section{$\mathrm{V}[\mathrm{T} \dot{\mathrm{H}} \mathrm{G} \mathrm{G} \mathrm{A} D$}

. levele

$\beta 11$

Est_p1

1 Est p1

YP_001310323

$2 \mathrm{10} \mathrm{Z}^{\mathrm{A}}$

AAA9 9002

AAB16939

3 AAC21862

4 CAA37863

作

$\alpha 7$

elecelelee

276 H G G AW PQI V D A I V V N T T Q R I F I .....

276 H A G AWPQIIDA IVGH T HKAAR PKS S

276 K. G T W KCIIVEA I A N L VND T S H.....

279 P S S V H G P I A E V I L I A T T R S A A ......

278 P LA A VHE P LAAA A I CAAH T RAA T V $\ldots$.

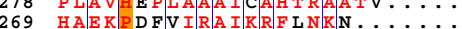

269 .

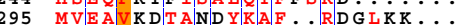

295 MVIEALDEITADDNYKAIF. . R S ILEAOR:

Figure 2 Conserved sequence blocks from multiple sequence alignment between Est_p1 and family V members of known 3D structure. Sequence alignment was performed using ClustalW version 2.0 and ESPript programs. Conserved sequences are indicated by box, and similar sequences are indicated by colored background. The catalytic triads are identical (red triangle). The alpha helix, beta sheet, random coil and beta turn are identical to $\alpha, \beta, \eta$ and $T$, respectively. 


\section{D model of Est_p1}

A model of Est_p1 was built using SWISS-MODEL Severs. Est_p1 displayed highest sequence homology with aclacinomycin methylesterase (accession code 1q0z) [28], with a modeled residue range from 4 to 293 amino acid (Figure 3A), and identity of $32 \%$. Structurally, Est_p1 consisted of two domains. The core domain, which includes the catalytic triad (residues 4$58,93-147,222-293)$, contained $5 \alpha$-helices $(\alpha 1-3,6,7)$ and $7 \beta$-sheets $(\beta 3-5,8-11)$. The second domain consisted of $2 \alpha$-helices $(\alpha 4,5$; residues 148-221) and $2 \beta$ sheets ( $\beta 6,7$; residues $59-92$ ), which formed a cap structure over the $\alpha / \beta$ catalytic sheet. A substrate binding pocket, $17.7 \AA$ long and $12.5 \AA$ wide, was formed inside the cap structure (Figure $3 \mathrm{~B}$ ).

The catalytic triad, $\mathrm{Ser}^{118}, \mathrm{Asp}^{244}$ and $\mathrm{His}^{272}$, were clustered close together at the bottom of this pocket. $\mathrm{Ser}^{118}$ was located within a nucleophile "elbow"

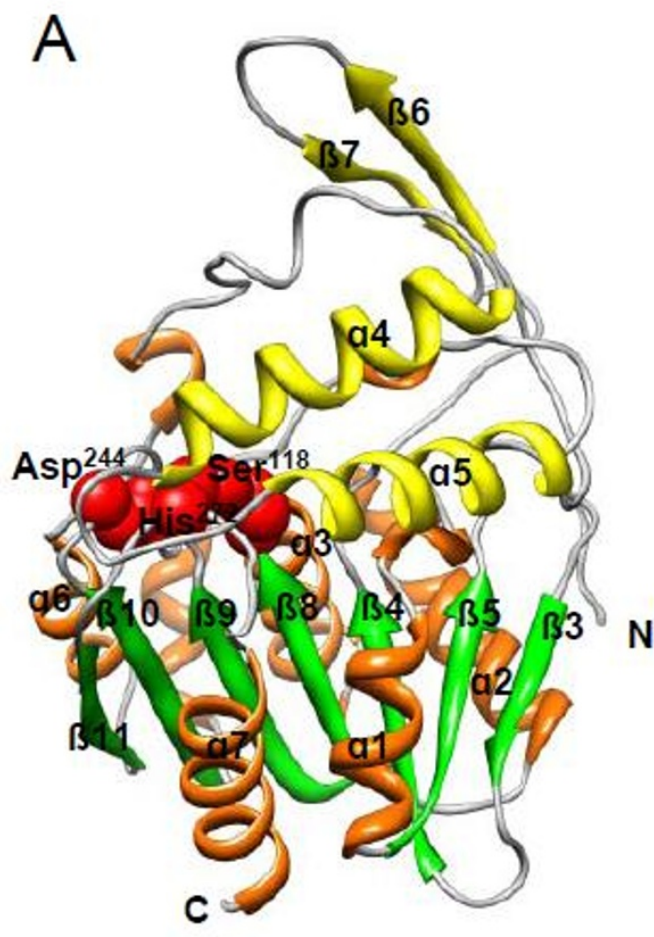

B
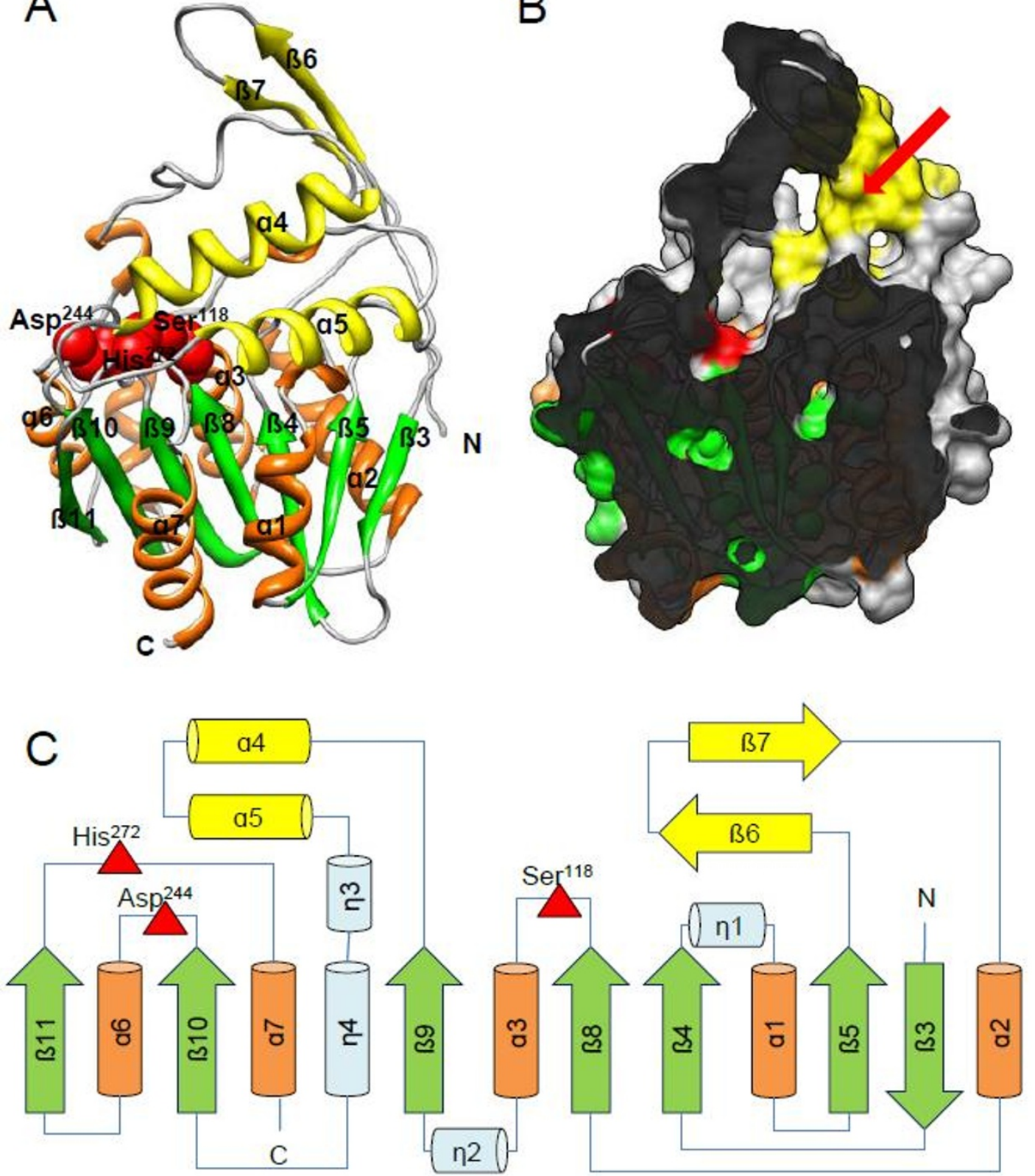

Figure 3 3D model of Est_p1. (A) Ribbon diagram of Est_p1 model. The central $\beta$-sheets and $\alpha$-helices in core domains are shown in green and orange, respectively. The cap structure is shown in yellow. Residues of the catalytic triad (Ser ${ }^{114}$, Asp ${ }^{244}$ and His ${ }^{272}$ ) are shown in red. (B) Cavity in the cap structure (shown in red arrow), acting as substrate binding pocket in Est_p1. (C) Topology diagram of Est_p1. 
connecting sheet $\beta 8$ and helix $\alpha 3$, while $\mathrm{Asp}^{244}$ and $\mathrm{His}^{272}$ were located on loops between $\beta 10-\alpha 6$ and $\beta 11$ $\alpha 7$, respectively (Figure $3 \mathrm{C}$ ).

\section{Characterization of Est_p1}

The full-length est_p1 gene was amplified and cloned into pET28a with a C-terminal $6 \times \mathrm{His}$ tag, then purified by Ni-NTA-agarose chromatography. The target protein appeared as a single band on SDS-PAGE with molecular weight $\sim 35.5 \mathrm{kDa}$ (Figure 4).

\section{Optimal $\mathrm{pH}$ and $\mathrm{pH}$ stability}

Optimal $\mathrm{pH}$ and $\mathrm{pH}$ stability of purified Est_p1 were determined using $\mathrm{C}_{4}$ as substrate. Est_p1 displayed highest activity at $\mathrm{pH}$ values between 8 and 10, and optimal $\mathrm{pH}$ is 8.57 (Figure $5 \mathrm{~A}$ ). The apparent $\mathrm{p} K_{\mathrm{a}}$ was 7.5. The $\mathrm{pH}$-dependent activity in serine carboxyl ester hydrolases is generally assumed to indicate involvement of the His residue in the catalytic triad [30]. However, no clear explanation for such mechanism has been established.

The $\mathrm{pH}$ stability was tested after incubation of purified Est_p1 for 90 to $400 \mathrm{~min}$ in various buffers at pHs between 3 and 11. After 90 min incubation, Est_p1 displayed $>70 \%$ residual activity in the $\mathrm{pH}$ range 6 to 8 . At pH 6.33 and 8.57, after 400 min incubation, residual activity decreased by $13 \%$ and $25 \%$, respectively, compared to that at $90 \mathrm{~min}$ (Figure $5 \mathrm{~B}$ ). At $\mathrm{pH} 7.33$, after 400 min incubation, residual activity decreased by only $1 \%$ compared to that at $90 \mathrm{~min}$. $\mathrm{pH}$ stability was therefore concluded to be greatest at $\mathrm{pH} 7.33$.

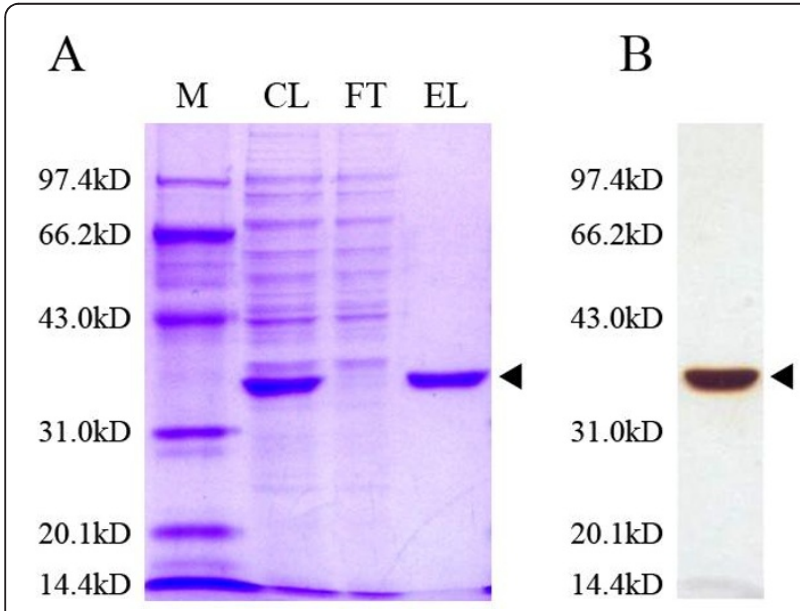

Figure 4 Purification of recombinant Est_p1. (A) Proteins recovered during various purification steps as described in the text were separated by SDS-10\% polyacrylamide gel electrophoresis, and stained with Coomassie Brilliant Blue R-250. Lane M, molecular weight standards; Lane $\mathrm{CL}$, induced cell lysate; Lane $\mathrm{FT}$, flowthrough; Lane EL, $50 \mathrm{mM}$ imidazole elution. (B) Silver staining of purified Est_p1. Protein size markers are indicated (kilo Daltons, kDa) at left. Recombinant Est_p1 proteins are indicated by arrow at right.

\section{Optimal temperature and thermostability}

This determination was made using $\mathrm{C}_{4}$ as a substrate, at $\mathrm{pH} 8.57$, with temperatures ranging from 0 to $60^{\circ} \mathrm{C}$. Esterase activity increased as temperature increased up to $40^{\circ} \mathrm{C}$, then decreased beyond that level. At temperatures above $55^{\circ} \mathrm{C}$, there was essentially no enzyme activity. The optimal temperature was $40^{\circ} \mathrm{C}$ (Figure 5C).

From the linear part of the Arrhenius plot between 0 and $40^{\circ} \mathrm{C}$, the activation energy for the formation of the enzyme/substrate complex was found to be $32.63 \mathrm{~kJ} /$ mol, similar to that of Pye3, another esterase of metagenomic origin [31]. The optimal temperature of Est_p1 was in the mesophilic range $\left(40^{\circ} \mathrm{C}\right)$, like those of most esterases isolated from marine origins so far $[32,33]$. The optimal temperature for activity of an enzyme is usually higher than the optimal temperature for growth of the organism $[19,34]$.

Thermostability of Est_p1 was determined by analysis of residual activity at regular intervals following preincubation of purified enzyme for durations up to $2 \mathrm{hr}$, at temperatures ranging from $30-50^{\circ} \mathrm{C}$. Est_p1 was stable, with residual activity $\sim 80 \%$, after incubation at 30 or $35^{\circ} \mathrm{C}$ for $2 \mathrm{hr}$. At $40^{\circ} \mathrm{C}$, the half-life was $\sim 63 \mathrm{~min}$ (Figure 5D). At 45 or $50^{\circ} \mathrm{C}$, residual activity dropped rapidly within $15 \mathrm{~min}$. These findings suggest that Est_p1 originated from a mesophilic microorganism [30].

\section{Substrate specificity}

Lipolytic enzymes are characterized by the ability to hydrolyze a wide range of fatty acid esters. The distinction between lipase and esterase depends on specificity of aliphatic chain length [35]. To determine the substrate specificity of Est_p1, we tested its effect on various $\rho$-Nitrophenyl esters having acyl chain lengths of $\mathrm{C}_{2}, \mathrm{C}_{4}, \mathrm{C}_{8}, \mathrm{C}_{10}, \mathrm{C}_{12}, \mathrm{C}_{16}$, and $\mathrm{C}_{18}$, under assay conditions of pH 8.57 and $40^{\circ} \mathrm{C}$. Est_p1 displayed hydrolytic activity for esters with short to medium chain length $\left(\mathrm{C}_{2}\right.$ to $\mathrm{C}_{10}$; maximal for $\mathrm{C}_{4}$ ), but no detectable activity for esters with long chain length $\left(C_{12}, C_{16}, C_{18}\right)$ (Table 1). Lipases are defined by preference for substrates with long acyl chains; therefore, these findings indicate that Est_p1 is an esterase (EC. 3.1.1.1).

The $\alpha / \beta$ hydrolase fold enzymes are characterized by a nucleophilic "elbow" with the conserved motif G-x-S-x$G$ [36]. An enzyme's substrate specificity is determined by a flexible sequence that changes conformation with the binding pocket, defined by hydrophobic amino acid residues that line the pocket [28]. In the present study, the binding pocket surface of Est_p1 was not constructed by a large number of hydrophobic residues, suggesting that the pocket can accommodate only a limited number of carbon atoms [23].

Both the $K_{\mathrm{m}}$ and $k_{\text {cat }}$ values of purified Est_p1 decreased as the acyl chain length increased up to $C_{4}$. 

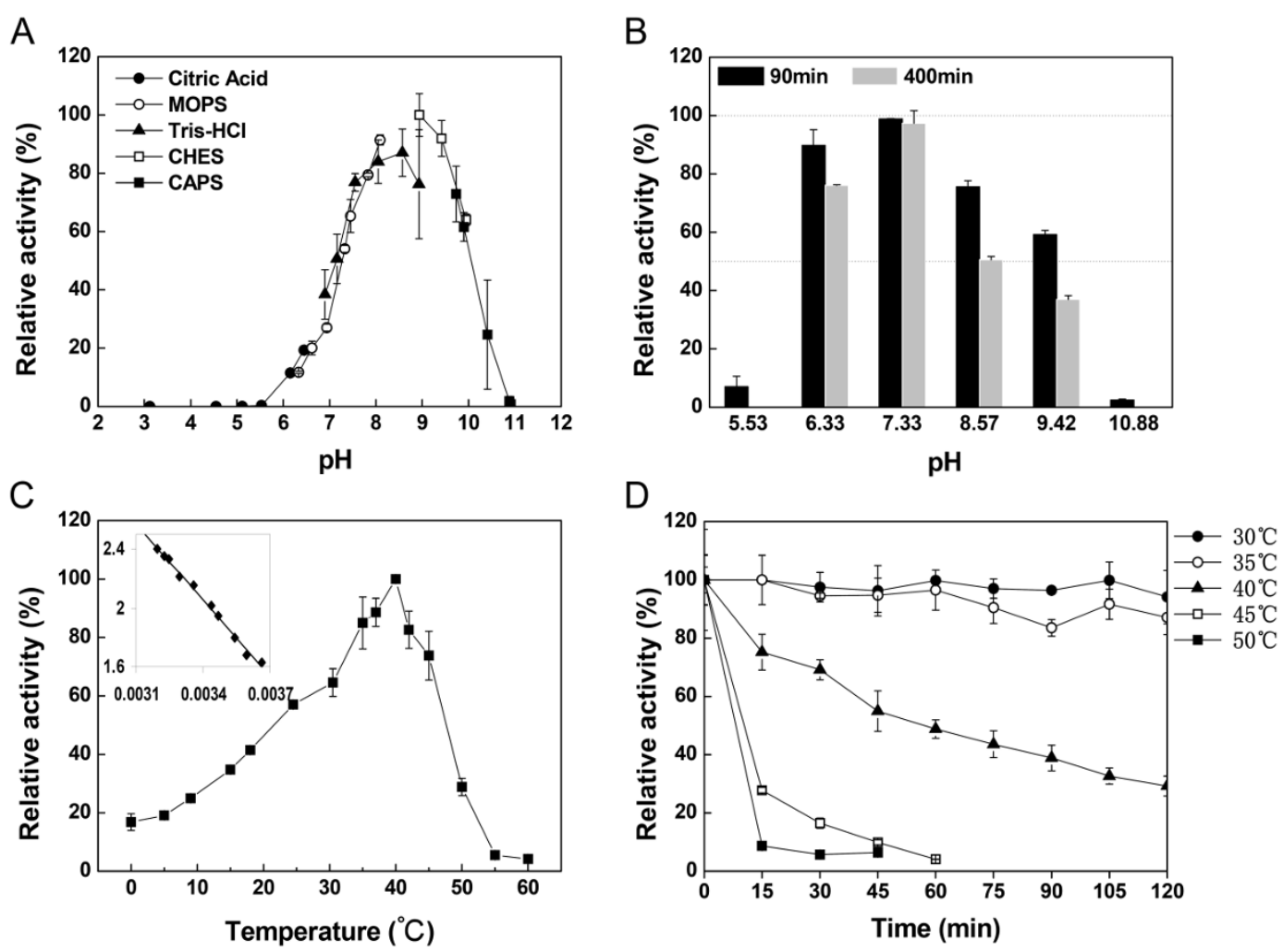

Figure 5 Biochemical characterization of Est_p1. (A) Effect of pH on Est_p1 activity. Est_p1 activity was measured at $40^{\circ} \mathrm{C}$ for 3 min in $50 \mathrm{mM}$ buffer, at various $\mathrm{pH}$ levels. Values are shown as percentage of maximal activity, defined as $100 \%$. Buffers used were sodium citrate (•), MOPS

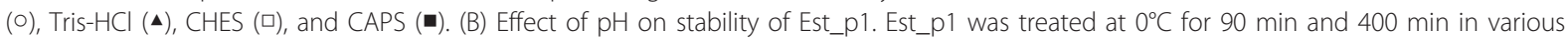
buffers at various $\mathrm{pH}$ levels. Residual enzyme activity was measured at $40^{\circ} \mathrm{C}$ in $50 \mathrm{mM}$ Tris-HCl buffer, $\mathrm{pH} 8.57$. Values are shown as percentage of original activity (measured in the same buffer and $\mathrm{pH}$, but without incubation at $0^{\circ} \mathrm{C}$ ), defined as $100 \%$. (C) Effect of temperature on Est_p1 activity. Activity was measured at various temperatures as indicated, for 3 min in $50 \mathrm{mM}$ Tris-HCl buffer, pH 8.57. Values are shown as percentage of maximal activity, defined as $100 \%$. The inset shows the temperature dependence as an Arrhenius plot. (D) Effect of temperature on stability of Est_p1. The enzyme was incubated in $50 \mathrm{mM}$ Tris-HCl buffer, $\mathrm{pH}$ 8.57, at various temperatures, for 120 min, and residual activity was measured at $40^{\circ} \mathrm{C}$ for 3 min at 15 min intervals. Residual activity was expressed in Panel B.

$K_{\mathrm{m}}$ value indicates the affinity of substrate for enzyme. $\mathrm{C}_{10}$ had the lowest $K_{\mathrm{m}}$ value $(0.17 \mathrm{mM})$, suggested that $\mathrm{C}_{10}$ structure is closer to the natural substrate of Est_p1. However, Est_p1 showed a specific preference for $\mathrm{C}_{4}$, which had the highest $k_{\text {cat }} / K_{\mathrm{m}}$ value $\left(11,500 \mathrm{~S}^{-1} \mathrm{mM}^{-1}\right)$ of any of the substrates; this value was 21-, 28-, and 14fold higher than that of $\mathrm{C}_{2}, \mathrm{C}_{8}$, and $\mathrm{C}_{10}$, respectively. $\mathrm{C}_{4}$ is the most appropriate substrate for Est_p1.

In general, there is a negative correlation between $K_{\mathrm{m}}$ and $k_{\mathrm{cat}}$ values for a particular enzyme toward different substrates, i.e., a low $K_{\mathrm{m}}$ value for a substrate indicates positive affinity for the enzyme, associated with higher catalytic activity and consequently a higher $k_{\text {cat }}$ value. In contrast, $K_{\mathrm{m}}$ and $k_{\text {cat }}$ values for Est_p1 showed a positive correlation, and were both higher for the appropriate substrate, $\mathrm{C}_{4}$, than for other substrates tested. Similar results were found for other metagenomic esterases with heterologous expression, most of which were expressed by His tagging on the $\mathrm{C}$ - or $\mathrm{N}$-terminus [31]. Addition of six hydrophilic His residues caused substrate specificity of the recombinant enzymes to shift toward more hydrophilic substrates [37].

Table 1 Kinetic parameters for various $\rho$-Nitrophenyl esters of Est_p1

\begin{tabular}{|c|c|c|c|c|}
\hline Substrate ( $\rho$-Nitrophenyl ester) & $K_{\mathrm{m}}(\mathrm{mM})$ & $\operatorname{Vmax}\left(\mu \mathrm{mol} \cdot \mathrm{min}^{-1} \cdot \mathrm{mg}^{-1}\right)$ & $k_{\text {cat }}\left(\mathrm{S}^{-1}\right)$ & $k_{\mathrm{cat}} / K_{\mathrm{m}}\left(\mathrm{S}^{-1} \mathrm{mM}^{-1}\right)$ \\
\hline Acetate $\left(C_{2}\right)$ & 0.585 & 244 & 315 & 543 \\
\hline Butyrate $\left(C_{4}\right)$ & 0.858 & 2,260 & 9,850 & 11,500 \\
\hline Caprylate $\left(C_{8}\right)$ & 0.348 & 109 & 140 & 401 \\
\hline Caprate $\left(C_{10}\right)$ & 0.170 & 31.6 & 138 & 809 \\
\hline
\end{tabular}


The kinetic studies indicated that recombinant Est_p1 had high specificity $\left(k_{\text {cat }} / K_{\mathrm{m}}\right.$ value $\left.11,500 \mathrm{~S}^{-1} \mathrm{mM}^{-1}\right)$ for substrate $\mathrm{C}_{4}$. This value is much higher than those reported for other metagenomic esterases, e.g., those from sludge samples at a South African mine refinery $\left(7.65 \mathrm{~S}^{-1} \mathrm{mM}^{-1}\right)$ [23], Antarctic desert soil $\left(14.8 \mathrm{~S}^{-1} \mathrm{mM}^{-1}\right)$ [38], tidal flat sediments $\left(18.2 \mathrm{~S}^{-1} \mathrm{mM}^{-1}\right)$ [39], marine environment $\left(26.7 \mathrm{~S}^{-1} \mathrm{mM}^{-1}\right)$ [16], hot springs in Tangkuban Perahu $\left(2,290 \mathrm{~S}^{-1} \mathrm{mM}^{-1}\right)$ [40] and hot springs in Thailand $\left(4,101.2 \mathrm{~S}^{-1} \mathrm{mM}^{-1}\right)$ [17].

Esterase is commonly used in production of enhancement the buttery flavor of the end product. Moreover, these enzymes which specificity towards short chain fatty acids, especially butanoic acid, are commercially available as potent flavoring tools [41]. In view of its high specificity and hydrolysis activity, Est_p1 has potential application in flavor industries requiring hydrolysis or synthesis of short chain esters.

Effects of solvents, detergents, metal ions and EDTA on Est_p1 activity

The activity of Est_p1 in various solvents and detergents was examined, as summarized in Table 2. In the case of solvents and detergents, SDS and PVPP inhibited enzymatic activity of Est_p1 at the concentration of $2 \mathrm{mM}$, whereas others displayed no significant effect on the hydrolytic activity of Est_p1.

In the case of metal ions, the higher concentrations displayed progressively greater inhibitory effect on Est_p1 activity, roughly in proportion to molecular weight. On the other hand, EDTA had no significant influence on Est_p1. The finding indicates that Est_p1 does not require the presence of co-factors, which also confirmed the Est_p1 has no metal-binding site structurally.

Lipolytic enzymes belong to the class of serine hydrolases, and their activity is generally found to be irreversibly inhibited by PMSF. However in our study, PMSF had no effect on catalytic activity of Est_p1, which was also rarely found in other two lipolytic enzymes $[24,42]$. Our finding suggests that the inhibitory effect of PMSF was eliminated by a lid structure in carboxylesterases [43]. The 3D model of Est_p1 (Figure 3) predicts that the entrance to the binding site is sheltered by $\beta 6$ and $\beta 7$, which act as a lid structure to protect the catalytic serine residue. Aromatic residues surrounding the serine (e.g., His, Trp) may play a steric role to prevent modification by PMSF.

\section{Conclusions}

Based on marine sediment metagenomic library was successfully constructed, a novel family V esterase gene, termed est_p1 was cloned and expressed in E. coli. The recombinant Est_p1 efficiently catalyzed hydrolysis of substrates with short-chain esters at $\mathrm{pH} 8.57,40^{\circ} \mathrm{C}$, and acts as an esterase (EC. 3.1.1.1). It was not sensitive to PMSF and does not require metal co-factors. The discovery that Est_p1 has high specificity and hydrolysis activity towards $\rho$-Nitrophenyl butyrate $\left(C_{4}\right)$, whose value was 21-, 28-, and 14-fold higher than that of $\mathrm{C}_{2}$, $\mathrm{C}_{8}$, and $\mathrm{C}_{10}$, demonstrating Est_p1 has potential application in flavor industry requiring hydrolysis or synthesis of short chain esters. Further study on application of the enzyme for releasing short chain fatty acids from the low flavor fat-rich matrices in order to enhance its highly appreciated flavor will be further investigated. In addition, further studies may provide important data for future application of the novel metagenomic esterases for promising biotechnological processes.

\section{Materials and methods}

Strains, plasmids, and marine sediment samples

Escherichia coli DH5 $\alpha$ and vector pUC18 were used for library cloning, E. coli BL21 (DE3) and pET-28a (+) (Novagen) was used for heterologous expression of target protein.

Marine sediment samples from the South China Sea were collected from 23 sampling sites, depth $<100 \mathrm{~m}$ (Additional file 1, Table S1) and stored at $4^{\circ} \mathrm{C}$ until DNA extraction.

\section{Metagenomic library construction and functional screening of lipolytic clones}

Metagenomic DNA was isolated according to described previously [44]. After purified DNA by pulsed field gel

Table 2 Effect of organic solvents and cations on activity of Est_p1

\begin{tabular}{|c|c|c|c|c|c|c|c|}
\hline \multirow[t]{2}{*}{ Solvent } & \multicolumn{3}{|c|}{ Relative activity (\%) } & \multirow[t]{2}{*}{ Cations } & \multicolumn{3}{|c|}{ Relative activity (\%) } \\
\hline & $0.5 \mathrm{mM}$ & $1 \mathrm{mM}$ & $2 \mathrm{mM}$ & & $0.5 \mathrm{mM}$ & $1 \mathrm{mM}$ & $2 \mathrm{mM}$ \\
\hline GITC & $113 \pm 0.8$ & $104 \pm 1$ & $93.7 \pm 8$ & $\mathrm{Mg}^{2+}$ & $97.6 \pm 12$ & $101 \pm 0.03$ & $86.7 \pm 3$ \\
\hline PMSF & $104 \pm 2$ & $110 \pm 3$ & $99.5 \pm 8$ & $\mathrm{Ca}^{2+}$ & $96.3 \pm 3$ & $86.5 \pm 1$ & $55.1 \pm 3$ \\
\hline PVPP & $85.6 \pm 3$ & $73.5 \pm 3$ & $58.6 \pm 3$ & $\mathrm{Mn}^{2+}$ & $78.0 \pm 6$ & $85.5 \pm 3$ & $63.5 \pm 2$ \\
\hline SDS & $99.5 \pm 2$ & $71.5 \pm 0.6$ & $30.0 \pm 1$ & $\mathrm{CO}^{2+}$ & $82.3 \pm 6$ & $79.6 \pm 14$ & $12.0 \pm 2$ \\
\hline Thiourea & $105 \pm 1$ & $95.6 \pm 6$ & $95.3 \pm 0$ & $\mathrm{Ni}^{2+}$ & $54.4 \pm 5$ & $39.1 \pm 7$ & $24.4 \pm 4$ \\
\hline Urea & $102 \pm 0.6$ & $105 \pm 2$ & $101 \pm 2$ & $\mathrm{Zn}^{2+}$ & $24.1 \pm 10$ & $24.6 \pm 5$ & $24.4 \pm 11$ \\
\hline EDTA & $110 \pm 18$ & $113 \pm 6$ & $108 \pm 5$ & $\mathrm{Cu}^{2+}$ & $19.1 \pm 0.1$ & $11.3 \pm 2$ & $4.11 \pm 1$ \\
\hline
\end{tabular}


electrophoresis (PFGE) (Bio-Rad CHEP Mapper XA, fixed angle 120, $4.5 \mathrm{~V} / \mathrm{cm}$, running time $15 \mathrm{hr}, 1-12 \mathrm{sec}$ switch, $15^{\circ} \mathrm{C}$ ), and the DNA was partially digested with Sau3AI. The recovered DNA fragments (size 2-9 kb) were ligated into pUC18 vectors, and then electroporated in $E$. coli DH5 $\alpha$. Lipolytic clones were detected based on their ability to hydrolyze tributyrin (1\%) substrate, and to produce a clear halo around the colony after $48 \mathrm{hr}$ incubation at $37^{\circ} \mathrm{C}$. All lipolytic clones were streaked to obtain single colonies, and re-tested for ability to hydrolyze tributyrin [14].

\section{Bioinformatic analysis}

The positive clones were confirmed by plasmid isolation and restriction enzyme digestion, and the unique plasmids were sent to a DNA sequencing facility (Invitrogen, Beijing, China) for primer-walking sequencing approach.

Sequences were screened for vector contamination and quality trimmed. Assembly and analysis were performed using DNAMAN (version 6.0, Lynnon Corp., Canada) and GENETYX (version 8.01, Genetyx Corp., Japan) programs, respectively. Open reading frames (ORFs) in each assembled sequence were identified using the ORF Finder at the National Centre for Biotechnology Information (NCBI) website. Amino acid sequences of each ORF were used to find the best match, and conserved domains, by protein-protein BLAST program at the NCBI website. The subfamily and superfamily of each encoded protein was determined by searching the Lipase Engineering Database $[45,46]$. Signal peptide and transmembrane domain were predicted using server SignalP and HMMTOP. Promoter prediction was conducted using Neural Network Promoter Prediction (NNPP) version 2.2. Positional frequency matrices (PFMs) of E. coli promoters were also used to predict positions of possible promoters [47]. Ribosome binding site (rbs) prediction was conducted using the PFMs [48]. Multiple sequence alignments were calculated using ClustalW and exported by ESPript. Phylogenetic relationships among lipolytic members in each protein family were analyzed by MEGA 4.0 [4]. The 3D model of Est_p1 was constructed by SWISS-MODEL http://swissmodel.expasy.org/ and presented using UCSF Chimera, version 1.4.1. The size of banding pocket was measured by the distances of atoms located at the pocket edge and also calculated by UCSF Chimera, version 1.4.1.

\section{Expression and purification of Est_p1}

Full-length $e s t$ p 1 gene was amplified from the plasmid nle1. The forward primer (5'-CATGCCATGGCAAACATTATTGCG-3') with the restriction enzyme site NcoI, and the reverse primer (5'-ACGCGTCGACGATA
AAAATTTTTTGGGT-3') with SalI, were designed to generate a $\mathrm{C}$-terminal His-tag of the recombinant target protein. The est_p1 gene was cloned into expression vector $\mathrm{pET}-28 \mathrm{a}(+)$, and was transformed into E. coli BL21 (DE3) cells. Transformants were grown on LB medium containing $50 \mu \mathrm{g} \mathrm{ml}{ }^{-1}$ kanamycin at $37^{\circ} \mathrm{C}$. When cells reached a density in the $0.5-1.0$ range at $600 \mathrm{~nm}$, they were induced for $16 \mathrm{hr}$ with $0.5 \mathrm{mM} \mathrm{IPTG}$ at $30^{\circ} \mathrm{C}$.

The target protein was purified by Ni-NTA (Qiagen) affinity chromatography, and protein concentration was determined using Lowry protein assay method, with BSA protein as standard. Purity of the protein was confirmed by SDS-PAGE, and protein bands were visualized by Coomassie Brilliant Blue R-250 and silver staining.

\section{Enzyme characterization}

Lipase/esterase activity was determined by a spectrophotometric method using $\rho$-Nitrophenyl $(\rho N P)$ esters. Catalytic activity of Est_p1 was examined using $\rho N P$ butyrate as standard substrate (unless indicated otherwise) at $40^{\circ} \mathrm{C}$ for $3 \mathrm{~min}$. The assay mixture contained 1 $\mathrm{mM} \rho \mathrm{NP}$ esters, $50 \mathrm{mM}$ Tri-HCl buffer ( $\mathrm{pH}$ 8.57), and $4 \%$ ethanol, in a total volume of $1 \mathrm{ml}$. Absorbance was measured at $405 \mathrm{~nm}$. One unit esterase was defined as the amount of enzyme needed to liberate $1 \mu \mathrm{mol} \rho \mathrm{NP}$ in $1 \mathrm{~min}$.

Optimal pH of purified Est_p1 was determined under standard conditions. Buffers used were $50 \mathrm{mM}$ of sodium citrate ( $\mathrm{pH} 3.12$ - 6.45), MOPS ( $\mathrm{pH} 6.33$ - 8.09), Tris- $\mathrm{HCl}$ (pH 6.9 - 8.93), CHES (pH 8.94 - 9.95) and CAPS (pH 9.73 - 10.88). The pH stability was determined by incubating the assays at various $\mathrm{pH}$ (5.53 to 10.88) for $90 \mathrm{~min}$ and $400 \mathrm{~min}$, and the residual activity was measured.

Optimal temperature was measured under standard conditions, in the range $0-60^{\circ} \mathrm{C}$. Thermostability was determined by incubating the assays at temperatures ranging from 30 to $50^{\circ} \mathrm{C}$ for $120 \mathrm{~min}$, and measuring residual activity.

Substrate range and specific activity were determined under standard conditions using $\rho \mathrm{NP}$ esters with acylchains of various lengths: $\rho N P$ acetate $\left(C_{2}\right), \rho N P$ butyrate $\left(C_{4}\right), \rho N P$ caprylate $\left(C_{8}\right), \rho N P$ caprate $\left(C_{10}\right), \rho N P$ laurate $\left(C_{12}\right)$, $\rho N P$ palmitate $\left(C_{16}\right)$, $\rho N P$ stearate $\left(C_{18}\right)$. Initial reaction velocities measured at various substrate concentrations were fitted to the Lineweaver-Burk transformation of the Michaelis-Menten equation. Kinetic analyses by curve fitting were performed with the Fit linear program (OriginLab Corp., USA).

Activity of purified Est_p1 was assayed under standard conditions in the presence of various potentially inhibitory reagents: divalent metal cation $\left(\mathrm{Mg}^{2+}, \mathrm{Ca}^{2+}, \mathrm{Mn}^{2+}\right.$, $\left.\mathrm{Co}^{2+}, \mathrm{Ni}^{2+}, \mathrm{Cu}^{2+}, \mathrm{Zn}^{2+}\right)(0.5,1$ and $2 \mathrm{mM})$, chelating 
agent (EDTA), inhibitor (PMSF), detergents (SDS, guanidine thiocyanate, thiourea, urea), and polar affinitive surfactant polyvinylpoly-pyrrolidone (PVPP) $(0.5,1$ and $2 \% \mathrm{w} / \mathrm{v})$.

\section{Nucleotide sequence accession number}

The amino acid sequence of Est_p1 is available at the GenBank database [GenBank: ACF33459].

\section{Additional material}

Additional file 1: Table S1 Designation, coordinates and depth of 23 marine sediment samples collected in the South China Sea. The information of marine sediment sample source. Table S2 Lipolytic enzymes from metagenomic library and compared to homologous proteins in GenBank. 15 Lipolytic enzyme genes were cloned from metagenomic library and their accession numbers in GenBank.

\section{Abbreviations}

GDSL: motif consensus amino acid sequence of Gly, Asp, Ser, and Leu around the active site Ser; PMSF: phenylmethylsulfonyl fluoride; GITC: guanidine thiocyanate; PVPP: polyvinylpolypyrrolidone; SDS: sodium dodecyl sulfate; EDTA: ethylenediaminetetraacetic acid; $C_{2}$ : $\rho$-Nitrophenyl acetate; $C_{4}$ : $\rho$-Nitrophenyl butyrate; $C_{8}$ : $\rho$-Nitrophenyl caprylate; $C_{10}$ : $\rho$-Nitrophenyl caprate; $C_{12}$ : $\rho$-Nitrophenyl laurate; $C_{16}: \rho$-Nitrophenyl palmitate; $C_{18}: \rho$ Nitrophenyl stearate.

\section{Acknowledgements}

We thank Dr. Yijun Huang for providing neritic environmental samples and also grateful to Dr. Steve Anderson for English correction of the manuscript. This study was supported by the Chinese Science and Technology Support Research for the $11^{\text {th }}$ 5-year Plan Program (Grant No. 2006BAD07A01), and the National Innovation Experiment Program for Chinese University Students (Grant No. 081001906).

\section{Author details}

${ }^{1}$ State Key Laboratories for Agro-biotechnology and College of Biological Sciences, China Agricultural University, Beijing, 100193, P. R. China. ${ }^{2}$ State Key Laboratory of Tropical Oceanography, South China Sea Institute of Oceanology, Chinese Academy of Sciences, Guangzhou, 510301, P. R. China.

\section{Authors' contributions}

YL, GHG, QP initiated and coordinated the project. QP and XZH performed construction of metagenomic library. QP, MS and XW performed gene cloning and expression in E. coli. QP, GLW and GHG were responsible for enzyme characterization. YL, BXL, GHG and YSW provided critical discussion. $\mathrm{QP}$ and $\mathrm{YL}$ wrote the paper and all authors approved the final version of the manuscript.

\section{Competing interests}

The authors declare that they have no competing interests.

Received: 3 October 2011 Accepted: 9 November 2011 Published: 9 November 2011

\section{References}

1. Kennedy J, Marchesi JR, Dobson ADW: Marine metagenomics: strategies for the discovery of novel enzymes with biotechnological applications from marine environments. Microbial Cell Factories 2008, 7:27.

2. Bowler C, Karl DM, Colwell RR: Microbial oceanography in a sea of opportunity. Nature 2009, 459:180-184.

3. Langridge G: Testing the water: marine metagenomics. Nature Reviews Microbiology 2009, 7:552-552.

4. Arpigny JL, Jaeger KE: Bacterial lipolytic enzymes: classification and properties. Biochemical Journal 1999, 343:177-183.
5. Gupta R, Gupta N, Rathi P: Bacterial lipases: an overview of production, purification and biochemical properties. Applied Microbiology and Biotechnology 2004, 64:763-781.

6. Jaeger KE, Reetz MT: Microbial lipases form versatile tools for biotechnology. Trends in Biotechnology 1998, 16:396-403.

7. Jaeger KE, Eggert T: Lipases for biotechnology. Current Opinion in Biotechnology 2002, 13:390-397.

8. Handelsman J: Metagenomics: Application of genomics to uncultured microorganisms. Microbiology and Molecular Biology Reviews 2004, 68:669-685.

9. Sleator RD, Shortall C, Hill C: Metagenomics. Letters in Applied Microbiology 2008, 47:361-366.

10. Lorenz P, Eck J: Metagenomics and industrial applications. Nature Reviews Microbiology 2005, 3:510-516.

11. Lee SW, Won K, Lim HK, Kim JC, Choi GJ, Cho KY: Screening for novel lipolytic enzymes from uncultured soil microorganisms. Applied Microbiology and Biotechnology 2004, 65:720-726.

12. Rhee JK, Ahn DG, Kim YG, Oh JW: New thermophilic and thermostable esterase with sequence similarity to the hormone-sensitive lipase family, cloned from a metagenomic library. Applied and Environmental Microbiology 2005, 71:817-825.

13. Rees HC, Grant S, Jones B, Grant WD, Heaphy S: Detecting cellulase and esterase enzyme activities encoded by novel genes present in environmental DNA libraries. Extremophiles 2003, 7:415-421.

14. Ranjan R, Grover A, Kapardar RK, Sharma R: Isolation of novel lipolytic genes from uncultured bacteria of pond water. Biochemical and Biophysical Research Communications 2005, 335:57-65.

15. Wu C, Sun BL: Identification of Novel Esterase from Metagenomic Library of Yangtze River. Journal of Microbiology and Biotechnology 2009, 19:187-193.

16. Kim JT, Kang SG, Woo JH, Lee JH, Jeong BC, Kim SJ: Screening and its potential application of lipolytic activity from a marine environment: characterization of a novel esterase from Yarrowia lipolytica CL180. Applied Microbiology and Biotechnology 2007, 74:820-828.

17. Tirawongsaroj P, Sriprang R, Harnpichamchai P, Thongaram T, Champreda V, Tanapongpipat S, Pootanakit K, Eurwilaichitr L: Novel thermophilic and thermostable lipolytic enzymes from a Thailand hot spring metagenomic library. Journal of Biotechnology 2008, 133:42-49.

18. Lorenz P, Liebeton K, Niehaus F, Eck J: Screening for novel enzymes for biocatalytic processes: accessing the metagenome as a resource of novel functional sequence space. Current Opinion in Biotechnology 2002, 13:572-577.

19. Hu Y, Fu C, Huang Y, Yin Y, Cheng G, Lei F, Lu N, Li J, Ashforth E, Zhang L, Zhu B: Novel lipolytic genes from the microbial metagenomic library of the South China Sea marine sediment. FEMS Microbiol Ecol 2010, 72:228-237.

20. Hong KS, Lim HK, Chung EA, Park EJ, Lee MT, Kim JC, Choi GJ, Cho KY, Lee SW: Selection and characterization of forest soil metagenome genes encoding lipolytic enzymes. Journal of Microbiology and Biotechnology 2007, 17:1655-1660.

21. Harrington ED, Singh AH, Doerks T, Letunic I, von Mering C, Jensen $L$, Raes J, Bork P: Quantitative assessment of protein function prediction from metagenomics shotgun sequences. Proceedings of the National Academy of Sciences of the United States of America 2007, 104:13913-13918.

22. Bendtsen JD, Nielsen H, von Heijne G, Brunak S: Improved prediction of signal peptides: SignalP 3.0. Journal of Molecular Biology 2004, 340:783-795

23. Rashamuse K, Ronneburg T, Hennessy F, Visser D, van Heerden E, Piater L, Litthauer D, Moller C, Brady D: Discovery of a novel carboxylesterase through functional screening of a pre-enriched environmental library. Journal of Applied Microbiology 2009, 106:1532-1539.

24. Chu XM, He HZ, Guo CQ, Sun BL: Identification of two novel esterases from a marine metagenomic library derived from South China Sea. Applied Microbiology and Biotechnology 2008, 80:615-625.

25. Feller G, Thiry M, Gerday C: Nucleotide sequence of the lipase gene lip2 from the antarctic psychrotroph Moraxella TA144 and site-specific mutagenesis of the conserved serine and histidine residues. DNA and Cell Biology 1991, 10:381-388.

26. Arpigny J, Feller G, Gerday C: Cloning, sequence and structural features of a lipase from the antarctic facultative psychrophile Psychrobacter immobilis B10. Biochim Biophys Acta 1993, 1171:331-333. 
27. Tatusov R, Mushegian A, Bork P, Brown N, Hayes W, Borodovsky M, Rudd K, Koonin E: Metabolism and evolution of Haemophilus influenzae deduced from a whole-genome comparison with Escherichia coli. Curr Biol 1996, 6:279-291.

28. Jansson A, Niemi J, Mantsala P, Schneider G: Crystal structure of aclacinomycin methylesterase with bound product analogues Implications for anthracycline recognition and mechanism. Journal of Biological Chemistry 2003, 278:39006-39013.

29. Chen J: Alcohol dehydrogenase: multiplicity and relatedness in the solvent-producing clostridia. FEMS Microbiol Rev 1995, 17:263-273.

30. Kim YJ, Choi GS, Kim SB, Yoon GS, Kim YS, Ryu YW: Screening and characterization of a novel esterase from a metagenomic library. Protein Expression and Purification 2006, 45:315-323.

31. Li G, Wang K, Liu YH: Molecular cloning and characterization of a novel pyrethroid-hydrolyzing esterase originating from the Metagenome. Microbial Cell Factories 2008, 7:38.

32. Hardeman F, Sjoling S: Metagenomic approach for the isolation of a novel low-temperature-active lipase from uncultured bacteria of marine sediment. Fems Microbiology Ecology 2007, 59:524-534.

33. Park HJ, Jeon JH, Kang SG, Lee JH, Lee SA, Kim HK: Functional expression and refolding of new alkaline esterase, EM2L8 from deep-sea sediment metagenome. Protein Expression and Purification 2007, 52:340-347.

34. Sheridan PP, Panasik N, Coombs JM, Brenchley JE: Approaches for deciphering the structural basis of low temperature enzyme activity. Biochimica Et Biophysica Acta-Protein Structure and Molecular Enzymology 2000, 1543:417-433.

35. Schmidt JA, Browning GF, Markham PF: Mycoplasma hyopneumoniae p65 surface lipoprotein is a lipolytic enzyme with a preference for shorterchain fatty acids. Journal of Bacteriology 2004, 186:5790-5798.

36. Nardini M, Dijkstra BW: alpha/beta hydrolase fold enzymes: the family keeps growing. Current Opinion in Structural Biology 1999, 9:732-737.

37. Lee $Y L$, Su MS, Huang TH, Shaw JF: C-terminal His-tagging results in substrate specificity changes of the thioesterase I from Escherichia coli. Journal of the American Oil Chemists Society 1999, 76:1113-1118.

38. Heath C, Hu XP, Cary SC, Cowan D: Identification of a Novel Alkaliphilic Esterase Active at Low Temperatures by Screening a Metagenomic Library from Antarctic Desert Soil. Applied and Environmental Microbiology 2009, 75:4657-4659.

39. Lee MH, Lee $\mathrm{CH}$, Oh TK, Song JK, Yoon JH: Isolation and characterization of a novel lipase from a metagenomic library of tidal flat sediments: Evidence for a new family of bacterial lipases. Applied and Environmental Microbiology 2006, 72:7406-7409.

40. Byun JS, Rhee JK, Kim ND, Yoon J, Kim DU, Koh E, Oh JW, Cho HS: Crystal structure of hyperthermophilic esterase EstE1 and the relationship between its dimerization and thermostability properties. Bmc Structural Biology 2007, 7:47.

41. Saerens K, Descamps D, Dewettinck K: Release of short chain fatty acids from cream lipids by commercial lipases and esterases. Biotechnology Letters 2008, 30:311-315.

42. Dharmsthiti S, Pratuangdejkul J, Theeragool G, Luchai S: Lipase activity and gene cloning of Acinetobacter calcoaceticus LP009. Journal of General and Applied Microbiology 1998, 44:139-145.

43. De Simone G, Menchise V, Manco G, Mandrich L, Sorrentino N, Lang D, Rossi M, Pedone C: The crystal structure of a hyper-thermophilic carboxylesterase from the archaeon Archaeoglobus fulgidus. Journal of Molecular Biology 2001, 314:507-518.

44. Zhou JZ, Bruns MA, Tiedje JM: DNA recovery from soils of diverse composition. Applied and Environmental Microbiology 1996, 62:316-322.

45. Pleiss J, Fischer M, Peiker M, Thiele C, Schmid RD: Lipase engineering database - Understanding and exploiting sequence-structure-function relationships. Journal of Molecular Catalysis B-Enzymatic 2000, 10:491-508.

46. Fischer $M$, Pleiss J: The Lipase Engineering Database: a navigation and analysis tool for protein families. Nucleic Acids Research 2003, 31:319-321.

47. Lisser S, Margalit H: Compilation of E. coli mRNA promoter sequences. Nucleic Acids Res 1993, 21:1507-1516.

48. Schneider T, Stephens R: Sequence logos: a new way to display consensus sequences. Nucleic Acids Res 1990, 18:6097-6100.

doi:10.1186/1475-2859-10-95

Cite this article as: Peng et al:: A novel esterase gene cloned from a metagenomic library from neritic sediments of the South China Sea. Microbial Cell Factories 2011 10:95

\section{Submit your next manuscript to BioMed Central and take full advantage of:}

- Convenient online submission

- Thorough peer review

- No space constraints or color figure charges

- Immediate publication on acceptance

- Inclusion in PubMed, CAS, Scopus and Google Scholar

- Research which is freely available for redistribution

Submit your manuscript at www.biomedcentral.com/submit 